\author{
Abstracta Iranica \\ Abstracta Iranica Revue bibliographique pour le domaine irano-aryen \\ Volume 42-43 | 2021 \\ Comptes rendus des publications de 2019-2020
}

\title{
Marek Jan Olbrycht. "Andragoras, a Seleukid Governor of Parthia-Hyrkania, and his Coinage"
}

\section{Leonardo Gregoratti}

\section{(2) OpenEdition}

1 Journals

\section{Electronic version}

URL: https://journals.openedition.org/abstractairanica/53309

DOI: 10.4000/abstractairanica.53309

ISSN: 1961-960X

Publisher:

CNRS (UMR 7528 Mondes iraniens et indiens), Éditions de l'IFRI

\section{Electronic reference}

Leonardo Gregoratti, "Marek Jan Olbrycht. "Andragoras, a Seleukid Governor of Parthia-Hyrkania, and his Coinage"', Abstracta Iranica [Online], Volume 42-43 | 2021, document 52, Online since 30 December 2021, connection on 20 December 2022. URL: http://journals.openedition.org/abstractairanica/53309 ; DOI: https://doi.org/10.4000/abstractairanica.53309

This text was automatically generated on 20 December 2022.

All rights reserved 


\title{
Marek Jan Olbrycht. “Andragoras, a Seleukid Governor of Parthia- Hyrkania, and his Coinage"
}

\author{
Leonardo Gregoratti
}

\section{REFERENCES}

Marek Jan Olbrycht. “Andragoras, a Seleukid Governor of Parthia-Hyrkania, and his Coinage", Dabir (The Digital Archive of Brief Notes \& Iran Review), 7, 2020, p. 192-200.

Marek Olbrycht deals with Andragoras, the Seleucid governor of Parthia, who according to Justin (41.4.6-8), was killed by Arsakes I once the Parthian invaded and took control of his satrapy. According to Wolski, the later historian Appian (Syr. 65) reported the revolt of the satrap Andragoras himself against the Seleucids a few years before Arsakes' coming into the scene (245 BC). A close analysis of the coins attributed to the supposedly disloyal satrap reveals characteristics that suggest a claim of independence from the central Seleucid power, including the display of the diadem and portrait traits similar to those of the contemporary king Antiochos II. The coinage and its geographical spreading suggest that Andragoras aspired to and enjoyed a substantial level of independence, even if he never officially claimed the title of king in both Parthia and Bactria, before the rise of Arsakes. 


\section{AUTHORS}

\section{LEONARDO GREGORATTI}

Durham University 